\title{
FOXG1 wt Allele
}

National Cancer Institute

\section{Source}

National Cancer Institute. FOXG1 wt Allele. NCI Thesaurus. Code C52899.

Human FOXG1 wild-type allele is located within $14 q 12-q 13$ and is approximately $4 \mathrm{~kb}$ in length. This allele, which encodes forkhead box protein $\mathrm{G} 1$, is involved in both the modulation of transcription by RNA polymerase II and in the regional development of the brain. 